\begin{tabular}{l|l|l|} 
CRITICAL & $\begin{array}{l}\text { Western Ghats } \\
\text { PARTNERSHIP FUND }\end{array}$ & Special Series \\
\cline { 2 - 3 } & &
\end{tabular}

\section{A checklist of freshwater fishes of the New Amarambalam Reserve Forest (NARF), Kerala, India}

\author{
Fibin Baby ${ }^{1}$, Josin Tharian ${ }^{1,2}$, Anvar Ali ${ }^{1}$ \& \\ Rajeev Raghavan ${ }^{1,3}$ \\ ${ }^{1}$ Conservation Research Group (CRG), St. Albert's College, \\ Cochin, Kerala 682018, India \\ ${ }^{2}$ Department of Zoology and Environmental Sciences, St. \\ John's College, Anchal, Kerala 691306, India \\ ${ }^{3}$ Durrell Institute of Conservation and Ecology (DICE), \\ University of Kent, Canterbury CT2 7NR, United Kingdom \\ Email: ${ }^{3}$ rajeevraq@hotmail.com (corresponding author)
}

The New Amarambalam Reserve Forest (NARF) $\left(11^{0} 14^{\prime}-11^{0} 24^{\prime} \mathrm{N} \& 7^{0} 19^{\prime}-76^{\circ} 33^{\prime} \mathrm{E}\right)$ covering an area of $265 \mathrm{~km}^{2}$ borders the Silent Valley National Park (Kerala State) and the Mukurthi National Park (Tamil Nadu State), and forms the core area of the Nilgiri Biosphere Reserve - an international biosphere reserve in the Western Ghats hotspot. NARF contains relatively unexploited natural evergreen and semi evergreen forests (Mathew \& Binoy 2002), as well as natural moist deciduous forest, teak and multi-species plantations (Kumar \& Yoganand

Date of publication (online): 26 November 2010

Date of publication (print): 26 November 2010

ISSN 0974-7907 (online) | 0974-7893 (print)

Editor: K. Rema Devi

Manuscript details:

Ms \# 02497

Received 30 June 2010

Final received 07 November 2010

Finally accepted 09 November 2010

Citation: Baby, F., J. Tharian, A. Ali \& R. Raghavan (2010). A checklis of freshwater fishes of the New Amarambalam Reserve Forest (NARF), Kerala, India. Journal of Threatened Taxa 2(12): 1330-1333.

Copyright: (c) Fibin Baby, Josin Tharian, Anvar Ali \& Rajeev Raghavan 2010. Creative Commons Attribution 3.0 Unported License. JoTT allows unrestricted use of this article in any medium for non-profit purposes, reproduction and distribution by providing adequate credit to the authors and the source of publication.

Acknowledgements: Funding for the study came from the Critica Ecosystem Partnership Fund (CEPF) Western Ghats Program through the Ashoka Trust for Research in Ecology and Environment (ATREE), Bengaluru, India. The authors thank K.K. Srivastava IFS (Chief Wildllife Warden, Government of Kerala) for permits, and Unnikrishnan (DFONilambur) and V.P. Jayaprakash (Range Office-Karulai, Nilambur) for logistics in the field. The unstinted cooperation and support of Simmy Solmon, Shylaja Menon and Ratheesh, Conservation Research Group St. Albert's College, Kochi is gratefully acknowledged.

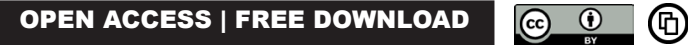

1999). NARF is an Important Bird Area (IBA) (Bird Life International 2009) and also harbours threatened and endemic mammals such as the

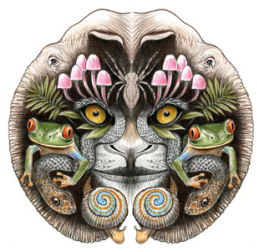
Nilgiri Tahr (Abraham et al. 2006).

NARF is drained by the river Chaliyar and its tributaries, Karimpuzha, Panapuzha, Manjakallanpuzha, Talipuzha and the Arikkayampuzha, forming a wide array of riverine microhabitats from cascades to riffles and pools. Although there have been limited studies on the fish fauna of Chaliyar (Lalmohan \& Devi 2000) and the Nilgiri Biosphere Reserve (Easa \& Basha 1995; Easa \& Shaji 1997), there is no information on the freshwater fish diversity of the NARF. As part of a larger project that is aimed at generating baseline data on the fish fauna of lesser known areas in the Kerala part of Western Ghats (CEPF-ATREE 2010), we carried out a survey of the fish species diversity in the NARF during April-May 2010. This contribution provides a checklist of the freshwater fish fauna of the NARF with notes on their threats and conservation needs.

We used a rapid assessment approach (Abd et al. 2009) as it was the most practical approach in terms of costs and logistics. Dawn (0500-0800 hr), dusk (1730$1930 \mathrm{hr}$ ), daytime (0800-1730 hr) and night (1930-0500 hr) sampling were carried out at fixed sites in the various tributaries draining the NARF including Karimpuzha (at Nedumkayam and Maanchery), Paanapuzha, Manjakkalanpuzha and Talipuzha (Fig. 1). Although electrofishing (using a backpack electroshocker) was the primary technique used for fish collection, we also employed a diverse array of active as well as passive gears including cast net, scoop net, drag net, gill net and traps. This was mainly because of the fact that electrofishing is considered to be the most effective sampling method for stream fishes, especially when sampling species at risk (Poos etal. 2007). The other gears were used so as to avoid sampling bias in specific habitats (for example - torrential stream reaches and cascades) where electrofishing was not possible. The use of an electroshocker also meant that we only collected minimum number of specimens as required for our study (especially threatened and restricted range endemics) and others were let off into the waters. Species level identification was carried out following Jayaram (1999) and Talwar \& Jhingaran (1991) and species names adhere to the CAS - Catalog of Fishes

\footnotetext{
This article forms part of a special series on the Western Ghats of India, disseminating the results of work supported by the Critical Ecosystem Partnership Fund (CEPF), a joint initiative of l'Agence Française de Développement, Conservation International, the Global Environment Facility, the Government of Japan, the MacArthur Foundation and the World Bank. A fundamental goal of CEPF is to ensure civil society is engaged in biodiversity conservation. Implementation of the CEPF investment program in the Western Ghats is led and coordinated by the Ashoka Trust for Research in Ecology and the Environment (ATREE).
} 


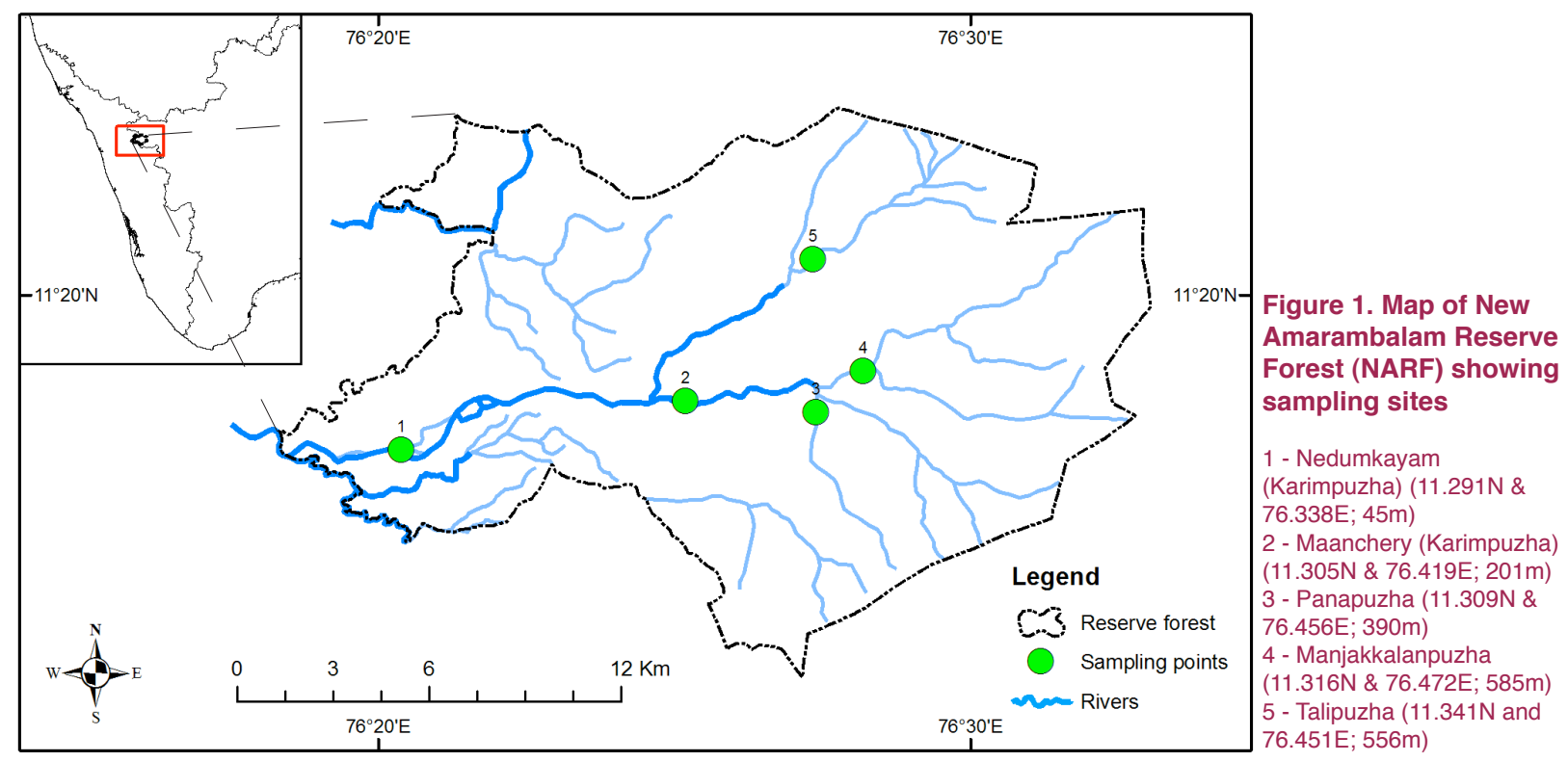

(Eschmeyer 2010).

We collected 43 species of freshwater fish belonging to 13 families and 28 genera (Table 1) from various tributaries of Chaliyar River, draining the NARF. Family Cyprinidae dominated with 20 species followed by Balitoridae and Bagridae (four species each). Of the 43 species collected, 20 species (46.51\%) were endemic to the Western Ghats hotspot with one species (Laubuca fasciata) strictly endemic to the Kerala region.

Among the various tributaries of Chalakudy draining the NARF, Karimpuzha had the highest species diversity $(S=39)$ followed by Talipuzha $(S=25)$ and Panapuzha $(S=19)$. Two locations in the Karimpuzha tributary, Nedumkayam and Maanchery have been previously explored for their fish diversity (Easa \& Basha 1995). During their survey, Easa \& Basha (1995) collected nine species from Nedumkayam area, whereas in the present study we could collect 29 species - an addition of 20 species. Two species recorded by Easa and Basha (1995) could not be collected by us in the course of the present survey. These were Channa orientalis, (which is a misidentification as this species is endemic to Sri Lanka) and Schismatogobius deraniyagalai. We collected 26 species from Maanchery, an addition of 11 species compared to the records of Easa \& Basha (1995) from the same locality. Deccan Mahseer Tor khudree recorded by Easa \& Basha (1995) could not be collected by us; we believe that the Mahseer species recorded by them was in fact Tor malabaricus and not T. khudree, as the identities of both these species were unclear, and only very recently confirmed (Silas et al. 2005). As there is no previous information on the fish diversity of the remaining tributaries of Chaliyar inside the NARF including Paanapuzha, Manjakkalanpuzha and Talipuzha, a comparison becomes difficult.
The fish diversity in NARF is high compared to various protected areas in the Nilgiri landscape such as Wyanad Wildlife Sanctuary $(S=34)$ and Silent Valley National Park (S = 19) in Kerala (Biju 2005) and the Mudumalai Wildlife Sanctuary $(S=38$ ) in Tamil Nadu (Manimekalan 1998). NARF harbours higher freshwater fish species diversity than in protected areas of northern Kerala (north of Palakkad gap). The number of species recorded in our current study $(S=43)$ is higher than those recorded from Aralam Wildlife Sanctuary, Kannur $(S=38)$, which was till date considered to be the protected area in northern Kerala with the highest fish species diversity (Biju 2005).

The streams inside NARF especially the Karimpuzha tributary needs to be designated as a priority area for freshwater fish conservation. Maanchery (and the nearby Mayiladipotty (11.304N \& 76.423E; 203m)), located in the Karimpuzha tributary need to be selected for long term protection and monitoring of fish diversity, as it harbours good population of two very important endemic species, Tor malabaricus and Glyptothorax annandalei. The absence of human habitation along the banks of this tributary except for settlements of the Cholanaicker and Kaatunaicker tribes means that there is no organized and large scale exploitation of these fishes. However, the fishing techniques used by these tribes are mainly destructive in nature and causes large scale mortality to the entire aquatic fauna present in the vicinity including fish, molluscs, crustaceans and insects. The most common destructive fishing techniques practices by the tribes include poisoning using leaves, barks and fruits of several trees such as Acacia torta, Randia brandisii and Zyzigium caryophyllaeum. There are also reports of fishing using dynamite by non-tribal communities residing along the fringes of the NARF (Anonymous 2009). There is hence an urgent need to create awareness among 
Table 1. List of fishes collected from the tributaries of Chaliyar River inside the New Amarambalam Reserve Forest

\begin{tabular}{|c|c|c|c|c|c|c|}
\hline Species & $E$ & 1 & 2 & 3 & 4 & 5 \\
\hline \multicolumn{7}{|l|}{ Cyprinidae } \\
\hline Barbodes carnaticus (Jerdon) & WG & & $\mathrm{C}$ & & & C \\
\hline Barilius bakeri Day & WG & $\mathrm{C}^{*}$ & $C^{*}$ & $\mathrm{C}$ & & C \\
\hline Barilius canarensis (Jerdon) & WG & & & & & $\mathrm{C}$ \\
\hline Barilius gatensis (Valenciennes) & WG & & & & & $\mathrm{R}$ \\
\hline Devario malabaricus (Jerdon) & & C & $C^{*}$ & & & C \\
\hline $\begin{array}{l}\text { Garra gotyla stenorhynchus } \\
\text { (Jerdon) }\end{array}$ & WG & & $C^{*}$ & C & C & C \\
\hline Garra mullya (Sykes) & & $C^{*}$ & $\mathrm{C}^{*}$ & C & $\mathrm{C}$ & C \\
\hline $\begin{array}{l}\text { Hypselobarbus curmuca } \\
\text { (Hamilton) }\end{array}$ & WG & $C^{*}$ & $\mathrm{C}^{*}$ & $\mathrm{C}$ & C & C \\
\hline Laubuca fasciata (Silas) & $\mathrm{K}$ & & $\mathrm{R}$ & & & $\mathrm{R}$ \\
\hline Osteochilus nashii (Day) & WG & & $\mathrm{R}^{*}$ & & & \\
\hline Puntius amphibius (Valenciennes) & & $\mathrm{C}$ & $\mathrm{C}^{*}$ & $\mathrm{C}$ & $\mathrm{C}$ & $\mathrm{C}$ \\
\hline Puntius denisonii (Day) & WG & $\mathrm{C}$ & $\mathrm{C}$ & C & & \\
\hline Puntius fasciatus (Jerdon) & & $\mathrm{C}$ & $\mathrm{C}$ & C & C & C \\
\hline $\begin{array}{l}\text { Puntius filamentosus } \\
\text { (Valenciennes) }\end{array}$ & & C & $C^{*}$ & $\mathrm{C}$ & & \\
\hline Puntius sarana (Hamilton) & & C & & & & \\
\hline Puntius ticto (Hamilton) & & $\mathrm{R}^{*}$ & & & & \\
\hline Puntius vittatus Day & & $\mathrm{C}$ & C & $\mathrm{C}$ & & \\
\hline Rasbora daniconius (Hamilton) & & $\mathrm{C}$ & & C & & C \\
\hline Salmophasia boopis (Day) & WG & & $\mathrm{R}^{*}$ & $\mathrm{R}$ & & $\mathrm{R}$ \\
\hline Tor malabaricus (Jerdon) & WG & $\mathrm{R}$ & $\mathrm{C}$ & $\mathrm{C}$ & C & C \\
\hline \multicolumn{7}{|l|}{ Balitoridae } \\
\hline Bhavania australis (Jerdon) & WG & & $\mathrm{C}^{*}$ & C & C & \\
\hline Nemacheilus guentheri Day & WG & C & $C^{*}$ & C & C & C \\
\hline Nemacheilus semiarmatus Day & WG & $\mathrm{C}$ & C & C & C & C \\
\hline Nemacheilus triangularis Day & WG & & $\mathrm{C}^{*}$ & & & $\mathrm{C}$ \\
\hline \multicolumn{7}{|l|}{ Cobitidae } \\
\hline $\begin{array}{l}\text { Lepidocephalus thermalis } \\
\text { (Valenciennes) }\end{array}$ & & & $\mathrm{R}^{*}$ & & & \\
\hline \multicolumn{7}{|l|}{ Bagridae } \\
\hline Batasio travancoria Hora and Law & WG & $\mathrm{R}$ & $\mathrm{R}$ & & & \\
\hline $\begin{array}{l}\text { Horabagrus brachysoma } \\
\text { (Gunther) }\end{array}$ & WG & $\mathrm{R}$ & & & & \\
\hline Mystus armatus (Day) & & $\mathrm{C}$ & C & & & \\
\hline Mystus malabaricus (Jerdon) & WG & & $\mathrm{R}$ & & & \\
\hline \multicolumn{7}{|l|}{ Siluridae } \\
\hline Ompok bimaculatus (Bloch) & & $\mathrm{R}$ & & & & \\
\hline \multicolumn{7}{|l|}{ Sisoridae } \\
\hline Glyptothorax anamalaiensis Silas & WG & & & & & $\mathrm{R}$ \\
\hline Glyptothorax annandalei Hora & & & C & C & C & C \\
\hline \multicolumn{7}{|l|}{ Aplocheilidae } \\
\hline $\begin{array}{l}\text { Aplocheilus lineatus } \\
\text { (Valenciennes) }\end{array}$ & & $\mathrm{R}^{*}$ & & & & \\
\hline
\end{tabular}

\begin{tabular}{|c|c|c|c|c|c|c|}
\hline Species & E & 1 & 2 & 3 & 4 & 5 \\
\hline \multicolumn{7}{|l|}{ Cichlidae } \\
\hline Etroplus maculatus (Bloch) & & $\mathrm{C}$ & & & & C \\
\hline Etroplus suratensis (Bloch) & & $\mathrm{R}$ & & & & \\
\hline \multicolumn{7}{|l|}{ Nandidae } \\
\hline Pristolepis marginata (Jerdon) & WG & $\mathrm{C}^{*}$ & $C^{*}$ & C & $\mathrm{R}$ & C \\
\hline \multicolumn{7}{|l|}{ Gobiidae } \\
\hline Glossogobius giuris (Hamilton) & & $\mathrm{R}^{*}$ & & $\mathrm{R}$ & & $\mathrm{R}$ \\
\hline Sicyopterus griseus (Day) & & & & $\mathrm{R}$ & & $\mathrm{R}$ \\
\hline \multicolumn{7}{|l|}{ Anabantidae } \\
\hline Anabas testudineus (Bloch) & & $\mathrm{R}$ & & & & \\
\hline \multicolumn{7}{|l|}{ Channidae } \\
\hline Channa marulius (Hamilton) & & $\mathrm{R}$ & & & & \\
\hline Channa striatus (Bloch) & & $\mathrm{R}$ & & & & \\
\hline \multicolumn{7}{|l|}{ Mastacembelidae } \\
\hline Macrognathus guentheri (Day) & & $\mathrm{R}$ & $\mathrm{R}$ & & & $\mathrm{R}$ \\
\hline $\begin{array}{l}\text { Mastacembelus armatus } \\
\text { (Lacepede) }\end{array}$ & & $\mathrm{R}$ & & & $\mathrm{R}$ & $\mathrm{R}$ \\
\hline
\end{tabular}

1 - Nedumkayam (Karimpuzha); 2 - Maanchery (Karimpuzha);

3 - Panapuzha; 4 - Manjakkalanpuzha; 5 - Talipuzha; E - Endemism; WG - Endemic to Western Ghats; K - Endemic to Kerala; C - Commonly seen ( $>20$ individuals - as a mean for a standard sampling effort in a day); $\mathrm{R}$ - Rarely seen (<20 individuals - as a mean for a standard sampling effort in a day); * - also recorded by Easa \& Basha (1995).

local communities including tribes on the importance of the stream habitat and its fish fauna, and the need to conserve them for future generations.

\section{REFERENCES}

Abd, I.M., C. Rubec \& B.W. Coad (2009). Key Biodiversity Areas: rapid assessment of fish fauna in southern Iraq. BioRisk 3: 161-171.

Abraham, S.K., P.S. Easa \& M. Sivaram (2006). Status and distribution of Nilgiri Tahr, Hemitragus hylocrius in Kerala part of Western Ghats. Zoos Print Journal 21(9): 2379-2385

Anonymous (2009). http://www.jelldragon.com/theoldways/ nilambur.htm. Accessed on 22 June 2010.

Biju, C.R. (2005). Habitat and Distribution of Hillstream Fishes of northern Kerala (north of Palghat Gap). PhD Thesis. Mahatma Gandhi University, Kottayam, India.

BirdLife International (2009). Important Bird Area factsheet: Amarambalam Reserved Forest - Nilambur, India. Downloaded from the Data Zone at http://www.birdlife.org on 23 June 2010

CEPF-ATREE (2010). http://www.atree.org/cepf_small_grants. Accessed on 21 st June 2010

Easa, P.S. \& S.C. Basha (1995). A Survey On The Habitat and Distribution of Stream Fishes in The Kerala Part of Nilgiri Biosphere Reserve. KFRI Research Report 86. Kerala Forest Research Institute, Thrissur, India, 86p.

Easa, P.S. \& C.P. Shaji (1997). Freshwater fish diversity in Kerala part of the Nilgiri Biosphere Reserve. Current Science 73(2): 180-182.

Eschmeyer, W.N. (ed.) (2010). Catalog of Fishes electronic 
version. http://research.calacademy.org/ichthyology/catalog/ fishcatmain.asp. Accessed on 24 June 2010

Jayaram, K.C. (1999). The Freshwater Fishes of The Indian Region. Narendra Publishing house, New Delhi, 396p.

Kumar, A. \& K. Yoganand (1999). Distribution and abundance of small carnivores in Nilgiri Biosphere Reserve, India. http:// wiienvis.nic.in/envisdec99/p74-86.htm. Accessed on 23 June 2010.

Lalmohan, R.S. \& K.R. Devi (2000). Fish fauna of the Chaliyar River, North Kerala, pp. 155-156. In: Ponniah, A.G. \& A. Gopalakrishnan (eds.). Endemic Fish Diversity of Western Ghats. NBFGR-NATP Publication. National Bureau of Fish Genetic Resources, Lucknow, U.P., India.

Manimekalan, A. (1998). The fishes of Mudumalai Wildlife Sanctuary, Tamil Nadu, South India. Journal of the Bombay Natural History Society 95(3): 431-443.
Mathew, G. \& C.F. Binoy (2002). Migration of butterflies (Lepidoptera:Rhopalocera) in the New Amarambalam Reserve Forest of the Nilgiri Biosphere Reserve. Zoos' Print Journal 17(8): 844-847.

Poos, M.S., N.E. Mandrak \& R.L. McLaughlin (2007). The effectiveness of two sampling methods for assessing imperiled freshwater fishes. Journal of Fish Biology 70: 691708.

Silas, E.G., A. Gopalakrishnan, L. John \& C.P. Shaji (2005). Genetic identity of Tor malabaricus (Jerdon) (Teleostei: Cyprinidae) as revealed by RAPD markers. Indian Journal of Fisheries 52(2): 125-140.

Talwar, P.K. \& A.G. Jhingran (1991). Inland Fishes of India and Adjacent Countries, Vol I \& II. Oxford \& IBH Publishing Co. Pvt. Ltd., New Delhi, 1158pp. 